polypharmacy, broadly anticipating the concerns of Lepping $\&$ Harborne. Finally, we respectfully suggest that the word polypharmacy be reconsidered, since pharmacy is seldom the originator of the plan!

1 Lepping P, Harbone GC. Polypharmacy: how bad are we really? Psychiatrist 2010; 34: 208-9.

2 Tungaraza TE, Gupta S, Jones J, Poole R, Slegg G. Polypharmacy and high-dose antipsychotic regimes in the community. Psychiatrist 2010; 34: 44-6.

3 National Institute for Health and Clinical Excellence. Schizophrenia: Core Interventions in the Treatment and Management of Schizophrenia in Primary and Secondary Care (Update) (CG82). NICE, 2009.

4 Taylor D. Antipsychotic polypharmacy - confusion reigns. Psychiatrist 2010; 34: 41-3.

Chandan Sehgal, Staff Grade Psychiatrist, South West Yorkshire Partnership NHS Foundation Trust, email: chandan.sehgal@swyt.nhs.uk, Paul A. Hardy, Pharmacy Services Manager, Fieldhead Hospital, Wakefield. doi: $10.1192 / \mathrm{pb} .34 .8 .354 \mathrm{a}$

\section{Wide of the mark}

It would seem that the basis for Christopher Cook's objection to our paper is our perspective on Charles Taylor's theory of the rise of secularity in the modern world. ${ }^{1}$ In doing so, he provides a skewed analysis of what we were actually saying. Taylor's work was helpful to us in considering psychiatry's attitude to religion. However, our main aim was to suggest that despite our deeply materialist age a sense of transcendent meaning was of great value to human beings and had never been lost. In this at least Cook seems to agree with us.

We were invited by the Editor to write a response to Harold Koenig's interesting suggestion that psychiatrists might pray with their patients. ${ }^{2}$ In doing so, we took the stance that a focus on the practice of praying with patients was distracting attention from the far greater issue of spirituality and meaning in people's lives. Cook appears to think we are against a thoughtful consideration of religion in psychiatry when that was never the case. He has missed our irony completely. One particular peer reviewer of our article had strikingly similar attitudes and forced our commentary through three revisions before they could accept it. The whole unhappy experience has made us worried about the increasing defensiveness of some religious psychiatrists in the College who appear to want to control discourse about psychiatry and religion. This should concern us all.

1 Cook CCH. Spirituality, secularity and religion in psychiatric practice. Commentary on ... Spirituality and religion in psychiatric practice. Psychiatrist 2010; 34: 193-5.

2 Koenig HG. Religion and mental health: what should psychiatrists do? Psychiatr Bull 2008; 32: 201-3.

Michael King, Professor of Psychiatry, University College London, email: m.king@medsch.ucl.ac.uk, Gerard Leavey, Professor in Mental Health and Wellbeing, Northern Ireland Association for Mental Health, and University of Ulster, Belfast.

doi: $10.1192 / \mathrm{pb} .34 .8 .355$

\section{Debating common ground and recognising differences}

It is good to discover that Michael King, Gerard Leavey and I share more common ground than I had at first perceived based on my reading of their article. ${ }^{1}$ Perhaps a part of the problem was that I only saw the abstract after publication and that what I had interpreted as ambivalence towards spirituality in the main body of the article is now set in the context of the clear and positive statement regarding spirituality that the abstract provides.

However, it seems that we do have a different reading of Charles Taylor's A Secular Age, ${ }^{2}$ and also probably hold different views of exactly what spirituality is. To explore these differences in academic debate seems to me to be a healthy thing, and this is why I was pleased to accept an invitation from the Editor to write a commentary on King \& Leavey's article. I would never wish to 'control discourse about psychiatry and religion' but I am glad to participate in a lively and critical debate about a subject that psychiatry has too long ignored and at times even denied.

1 King M, Leavey G. Spirituality and religion in psychiatric practice: why all the fuss? Psychiatrist 2010; 34: 190-3.

2 Taylor C. A Secular Age. Harvard University Press (Belknap), 2007.

Christopher C. H. Cook, Professorial Research Fellow, Durham University, email: c.c.h.cook@durham.ac.uk

doi: $10.1192 / \mathrm{pb} .34 .8 .355 \mathrm{a}$

\section{Spirituality, secularism and religion}

The controversial claim of French philosopher André Comte-Sponville that spirituality is quite compatible with atheism could provide vital insights to continued discussion on the relevance of religion to psychiatry which began in The Psychiatrist with the article by Dein et al. ${ }^{1,2}$

Handling debates about the existence or otherwise of God can be difficult, unless one is a trained philosopher. Comte-Sponville summarises it best when he tells us that at the age of 18 he wrote: 'If God exists then nothing follows; if God does not exist then nothing follows.' However, a few years later he wrote: 'If God exists everything follows; if God does not exist then everything follows.'

Religious systems depending on God as their pivotal point are in essence only relying on what human beings regard as the relevance of the Divine in human life. Those who have abandoned a belief in God also create what they think are the principles of life without God. They are all human creations.

Today we are surrounded by a variety of religions and ideologies and each of us as individuals makes our own evaluation of life and develops the values by which we live.

Many seem unwilling to take a serious part in any further discussion on the subject and seek only to abide by the law, live on good terms with others and follow the mores of the workplace. Many, like me, see the world as best understood in humanist terms. This means that we start and finish with ourselves. However, this does not prevent us from reaching out to others and beyond to the principles on which life is built.

There was an older humanism that seemed determined to negate all religion and to attempt to rebuild the world on a new atheistic agenda, but there can also be a humanism that seeks to understand the beliefs that are part of human evolution, both individually and collectively, and to reapply them to current needs.

The new great interest in the spirituality of patients is to be welcomed but there is a risk that it will become just another part of service provision without fully regarding its complexity. 